\title{
Influence of Jasmine oil and Methyl Jasmonate on Gene Expression and Menthol Production in Mentha
}

\author{
Omneya Farouk Abu El-Leel ${ }^{1}$, S. Y. Mohamed ${ }^{2}$, Noha A. Sukar ${ }^{3 *}$ and M. H. Abd EL-Aziz ${ }^{4}$ \\ ${ }^{1}$ Horticulture Research Institute (HRI), Agric ultural Research Centre (ARC), Cairo, Egypt. \\ ${ }^{2}$ Decidious fruit tree Res. Dept., Horticulture Research Institute (HRI), Agricultural Research Centre \\ (ARC), Cairo, Egypt. \\ ${ }^{3}$ Biological and Environmental Sciences Dept., Fac. of Home Economics, Al Azhar University, Egypt \\ ${ }^{4}$ Dept. of Genetics, Fac. of Agric., Mansoura University. Egypt \\ *Corresponding author; E-mail: nrr1611@yahoo.com, nohaaldesoky@azhar.edu.eg
}

Received on: 7-6-2021

Accepted on: 29-6-2021

\begin{abstract}
Mentha is the major source of menthol used for many important commercial and pharmaceutical purposes. For enhanced menthol production, this study aimed to assess the influence of the foliar application of Jasmine oil and Methyl Jasmonate by 0.05 and $0.1 \%$ on gene expression, es sential oil, and its component especially Menthol in Mentha piperita L. Exogenously foliar application of Methyl Jasmonate (MeJA) and Jasmine oil (JO) treatments induced alteration of gene expression patterns which was detected by a cDNA-SCoT technique with high informative and discrimination capability. Where it targeted 33 clear trans cript-derived amplicons, 21 out of themwere new transcripts. Differential expression analysis of these patterns illustrated that the higher influence was by Jasmine oil with concentration $0.1 \%$ at $48 \mathrm{~h}$ followed by MeJA- $0.1 \%$ at $24 \mathrm{~h}$. On the other hand, mfs -transcripts were differentially regulated by MeJA and JO treatments. In general, the results revealed high level of volatile oil, high percentages of menthol (1.52 and 1.47-fold) with the low percentages of the menthone (0.69 and 0.77- fold), lowest level of upregulated menthofuran gene expression ( -0.88 and $\left.-0.72 \log _{2} \mathrm{FC}\right)$. Besides, good vegetative growth relative to the control was found with exogenously foliar application of MeJA by $0.05 \%$ after $48 \mathrm{~h}$ and JO by $0.1 \%$ after $24 \mathrm{~h}$, which increases the pharmacological quality of Menthaplant. Subsequently, indicating the possibility of using JO (Low-cost) after further study as a stimulantfor the activity of menthol production with high quality as a cheaper alternative to exogenously foliar application of MeJA.
\end{abstract}

KEYWORDS: Mentha, Menthol, Menthofuran, Volatile oil, Methyl Jasmonate, Jasmine oil, Differential expression, cDNA-SCoT, qPCR.

\section{INTRODUCTION}

Peppermint (Mentha piperita L.) from the family Lamiaceae is an aromatic perennial herb that containing more than 25 species as well as many varieties obtained by natural hybridization. It is the natural hybrid $(2 \mathrm{n}=6 \mathrm{x}=72)$ between $M$. spicata $\mathrm{L}$. (spearmint, $2 \mathrm{n}=48$ ) and $M$. aquatica $\mathrm{L}$. (water mint, $2 \mathrm{n}=$ 96) (Kokkini 1991; Banthorpe 1996; Pushpangadan and Tewari, 2006). They are of major medicinal and aromatic crops and cultivated widely for their essential oil (Inoue et al., 2003) Menthol, the main component of Mentha oil, is found in the highest concentrations in mature leaves (Fahlen et al., 1997; Rohloff 1999). Mentha genus plants produce a natural chemical product group known as monoterpenes and are the only source to produce menthol throughout the world (Chakraborty and Chattopadhyay, 2008). Also, some parts from Menta plants are used as condiments and herbal teas in fresh or dried form due to their featured aroma (Baser and Kurkcuoglu 1999). Menthol has wide industrial uses, where used in food additives and many medicinal applications such as oral hygiene (Eccles 1994; Patel et al., 2007). Where is used to enhance the skin penetration of many medicinal compounds and it has unlimited potential to be developed into pharmaceutical compounds and synthetically modified drugs (Galeotti et al., 2001; Kamatou et al., 2013). Limonene synthase represents the obliged menthol biosynthesis step. In Mentha essential oil, limonene is a precursor to carvone. (Kjonaas and Croteau 1983). The conversion from the pathway to menthol is important to the diversion of pulegone to menthofuran catalyzed by menthofuran synthase which is considered one of the metabolites stress produced by the peppermint plant under extreme abiotic stress conditions during the leaf expansion period. It is one of the important strategies that 
plants develop to increase stress tolerance (Afkar et al., 2013). Nucleic acids, lipids and proteins as organic molecules are prone to be degradation damage (Galeotti et al., 2001). Stress response mechanisms are activated through these conditions, either to promote or to prevent the rapid turnover the source of damaged molecules (Miranda, 2011). These strategies involve alters in the gene expression, metabolism, and some metabolites production (Ramanjulu and Bartels 2002; Staswick and Howell 1992). However, menthofuran is a highly toxic organic compound that increases in the essential oil of Mentha under different stress conditions. It is metabolically metabolized to produce hepatotoxic chemically reactive intermediates (Anderson et al., 1996; Thomassen et al., 1992). Expression reduction of Menthofuran Synthase gene ( $m f s)$ causes improvement of essential oil quality (Rahimi et al., 2017). Plant defence responses, on the other hand, are controlled by a complex network of signaling channels that include endogenous signaling molecules, such as Saicylic acid SA and Jasmonic acid. Jasmonic acid (JA) and its methyl ester or Methyl Jasmonate (MeJA) which first isolated from jasmine oil (JO) have been reported to play an important role in the signal transportation process that regulates defense genes in plants (Farmer and Ryan 1990).

Regulation of plant grow th and development is by a balance between the action of different groups of growth regulators, which promote or inhibit such processes (Prins et al., 2010). Where MeJA is considered a cellular regulator that plays an important role in plant development and many physiological processes and abiotic stresses (Maciejewska et al., 2004; Choi et al., 2005; Warabieda and Olszak 2010; Kim et al., 2009). In addition, MeJA induces the biosynthesis of many secondary metabolites that play important roles in the adaptation of plants to particular environments (Choi et al., 2005). Jasmonic acid (JA) and its derivatives were collectively called Jasmonates (JAs).

The role of Jasmonates and their derivatives which collectively called Jasmonates (JAs) in controlling gene expression and secondary metabolism is so complicated (Farmer and Ryan, 1990). Choi et al., 1994 reported that JAs differentially regulate $\beta$-Hydroxy $\beta$-methylglutarylCoA reductase genes in potato. Also in cell cultures of Taxus canadensis, MeJA induced the diterpene taxol accumulation and that accumulation was correlated with the induced expression of two genes coding for taxadiene synthase and downstream biosynthetic enzymes (Hefner et al., 1998). Faldt et al., 2003 and Martin et al., 2002 showed that treatment of Norway spruce with MeJA stimulates gene expression of monoterpene and diterpene synthases.

cDNA SCoT (cDNA starts codon-targeted) molecular technique has been proposed to be an appropriate powerful tool for identification variations of gene expression, stress tolerance and genetic stability in plants (Al-Taweel et al., 2019). This method is an advantageous method compared to all other existing ones because it is cheaper, relatively more efficient, simpler to operate, faster and can be readily reproduced of the results (Luo et al., 2014). cDNA-SCoT markers were used to determine the gene expression in Saccharum officinarum, Phoenix dactylifera, Mangiferaindica, sugarcane, Olive tree and Dendrobium officinales (Munns and Tester, 2008; Chen, et al., 2013; ALJanabi and Al-Rawi, 2018).

More accurately, RT-PCR (reverse transcriptase-dependent polymerase chain reaction) can quantify a few molecules of a particular mRNA in extremely small amounts of starting material. Originally, this approach was created for medical purposes. Although it is commonly employed to assess the existence or absence of a certain transcript in plants, it has also been used to measure gene expression levels (Chang et al., 1993 and Fleming et al., 1996). Despite the higher accuracy of real-time PCR, semi-quantitative RT-PCR offers advantages in sensitivity and specificity, as well as a broad range of detection. The semi-quantitative RT-PCR technique is still vastly employed for many reasons in plant studies (Tang et al., 2007). The fact that this approach combines classical PCR and real-time PCR at a reasonable cost is the fundamental reason for its widespread adoption (Marone et al., 2001). Also, this technique was confirmed to generate good results compared to more advanced techniques (Souza et al., 2009).

Due to inadequate data about the effect of Jasmine oil (JO) (low-cost) versus MeJA(high-cost) on Mentha, the current study was designed to look at the effects of exogenously foliar application of JO and MeJA on gene expression patterns, specifically expression of the menthofuran synthase gene, volatile oil percent and compositions, and vegetative traits in Mentha.

\section{MATERIALS AND METHODS}

Our goals were studying the effect of $\mathrm{JO}$ and MeJA on growth, yield, Volatile oil (VO) (quantity, quality, and composition) and expression of menthofuran gene in Mentha (Mentha piperita L.). The experiment was conducted at research farm and Biotechnology Lab. of Horticultural Research Institute (HRI), Agricultural Research Centre (ARC) and in Seed and Tissue Pathology Lab, Faculty of Agriculture, Mansoura University in season 
2019/2020. Two months old seedlings were obtained from the Experimental Farm of Medicinal and Aromatic Plants Research Department, El Kanater El Khairia, Egypt. The peppermint plants initiated from $10 \mathrm{~cm}$ long rhizome cuttings followed by transferring into pots. Complete randomized design (CRD) was used with six replicates. Plants sprayed with Jasmine oil (JO) and Methyl Jasmonate (MeJA) as 0.05 and 0.1 in 2 percent of ethanol $(\mathrm{v} / \mathrm{v})$. The sprayed were onto peppermint plants during the early bloom stage. The treated plants were left on open air for 2 hours till JO and MeJA completely evaporated. At 0, 24, and 48 hours following treatment, leaves from untreated (control) and treated peppermint plants were randomly selected. Prior to RNA extraction, the leaves were instantly frozen in liquid nitrogen and stored at $-80{ }^{\circ} \mathrm{C}$.

\subsection{RNA isolation and cDNA synthesis}

Total RNA was isolated from leaves samples both untreated (control) and treated peppermint plants using TRIzol® reagent. Then, cDNA synthesis in Techni TC-512 PCR system using Thermo Scientific Kit (RevertAid ${ }^{\mathrm{TM}}$ First Strand cDNA Synthesis) was done as described by Abd El-Aziz et al. (2019).

\section{2. cDNA-SCoT amplification and detection}

The PCR reaction was performed in a total volume of $25 \mu \mathrm{l}$ using the SCoT primers for the study of expression profiling. These primers were selected from the literature according to Collard and Mackill (2009). The cDNA concentration was about $40 \mathrm{ng}$ for PCR amplification with SCoT primer (30 pmol). The PCR amplification and gel electrophoresis were carried out in Techni TC-512 Thermal Cycler and mini submarine gel BioRad respectively, as described by Abd El-Aziz et al. (2019). Besides, banding patterns were photographed using Bio-1D Gel Documentation system.

\subsection{Gel reading and analysis of cDNA-SCoT expression banding patterns}

cDNA-SCoT expression banding patterns were analyzed by GelAnalyzer3 (Egygene) softw are. Visible transcript-derived amplic ons (TD-amplicons or cDNA-amplicons) identified by the cDNA-SCoT analysis were scored for each primer and entered in the form of a $0 \& 1$ binary data matrix. From this matrix, the cDNA-SCoT profile was performed according to Adhikari et al. (2015) with color discrimination for the three types of TD-amplicons: TD-amplicons whose enhanced their genes by one or more treatments (TDE-amplicons), TD-amplicons whose silenced their genes by one or more treatments (TDS-amplicons), and monomorphic TD- amplicons with control (MTD-amplicons). Polymorphic information content (PIC) and resolving power $(\mathrm{Rp})$ were calculated to evaluate SCoT-primers efficiency according to Gorji et al. (2011); Prevost and Wilkinson (1999) respectively. The band intensity of monomorphic TD-amplicons with control were measured using GelAnalyzer 2010 software for comparison on its basis among treatments and control

\subsection{Semi-quantitative RT-PCR.}

Specific primer pairs used for gene expression analysis were designed as follow:

For target gene menthofuran synthase $(m f s)$ gene (Gene Bank: AF346833.1) according to Afkar et al. (2013) were:

$m f s$ F: 5-TCTACGCCTACATCCACCTTTC -3' $m f s$ R: 5 -CCTCCGCTCTATCTCCATTACC -3`

For normalization of target gene expression level, actin-1 gene (act) (Gene Bank: KM044035.1) was used as an internal standard or reference gene according to Rahimi et al. (2017), the primer pairs for this gene were:

act $\mathrm{F}$ : 5-CTACGAAGGCTACGCACTCC-3

act R: 5-GCAATGTAGGCCAGCTTCTC-3

These primers target specific amplicons of $341 \mathrm{bp}$ for $m f s$ gene and $165 \mathrm{bp}$ for act gene and were procured from Biobasic Com. PCR was performed based on the cDNA samples with primers (5 pmol) and Master Mix (Gendirect, Germany). According to Martiansyah et at., (2018), in Semiquantitative RT-PCR analysis, the PCR product is clearly visible on an agarose gel at the $30^{\text {th }}$ cycle and can be quantified in comparison to the reference gene. So, amplifications were performed with the following program: $94^{\circ} \mathrm{C}$ for $2 \mathrm{~min}$, followed by 30 cycles of $94{ }^{\circ} \mathrm{C}$ for $45 \mathrm{~s}, 53{ }^{\circ} \mathrm{C}$ for $m f s$ gene and 54 ${ }^{\circ} \mathrm{C}$ for act gene for $45 \mathrm{~s}$, and $72{ }^{\circ} \mathrm{C}$ for $45 \mathrm{~s}$. PCR products with 100-bp DNA ladder standards (Gendirect, Germany) were analyzed in $1.5 \%(\mathrm{w} / \mathrm{v})$ agarose gel, stained with ethidium bromide, and photographed using Bio-1D Gel Documentation system. Also, according to Martiansyah et al. (2018), the band intensity for PCR products as expression units were measured using GelAnalyzer 2010 softw are.

Expression ratio (ER) was calculated by the equation:

$\mathrm{ER}=$ expression unit of target gene /expression unit of the reference gene.

The relative fold change (FC) can then be calculated between treated samples normalized to the reference gene by the equation:

$\mathrm{FC}=\mathrm{ER}$ of treated sample/ ER of the control sample Ultimately, this value was transformed to $\log 2$ according to Youssef et al. (2014). 


\subsection{Determination of volatile oil percentage}

Volatile oil percentage (\%) was estimated from all samples as described in the (British Pharmacopeia, 1963).

\subsection{Determination of volatile oil composition:}

Samples taken for the volatile oil were analyzed using DsChrom 6200 Gas Liquid Chromatography (GLC) equipped with a flame ionization detector for separation of volatile oil constituents as described by Bunzen et al., 1969 and Hoftman, 1967.

\subsection{Vegetative data:}

At the end of season (after 3 months from bloom stage), data of vegetative traits were recorded on untreated and treated peppermint plants. These traits were: Plant height $(\mathrm{cm})$, Fresh weight /plant (g), Dry weight/plant (g), Number of leaves/plant and Leaf area/plant $\left(\mathrm{cm}^{2}\right)$

The results of volatile oil percentage and vegetative data for treated and untreated plant were analyzed by one-way analysis of variance and comparison of means using the Tukey method and $95 \%$ confidence (at the level $\mathrm{P}<0.05$ ) by Minitab 17.1.0 software.

\section{RESULS AND DISCUSSION}

\subsection{Differential expression analysis using cDNA-SCoT Technique:}

In this study, cDNA-SCoT technique was applied for the first time to analyze the gene expression variations induced by exogenously foliar application of MeJA and JO treatments. The cDNA SCoT can be easily used to analyze the overall levels of the plant tissue transcriptions at the same time, which is especially important for differential expression analysis ( $\mathrm{Wu}$ et al., 2013). So, to

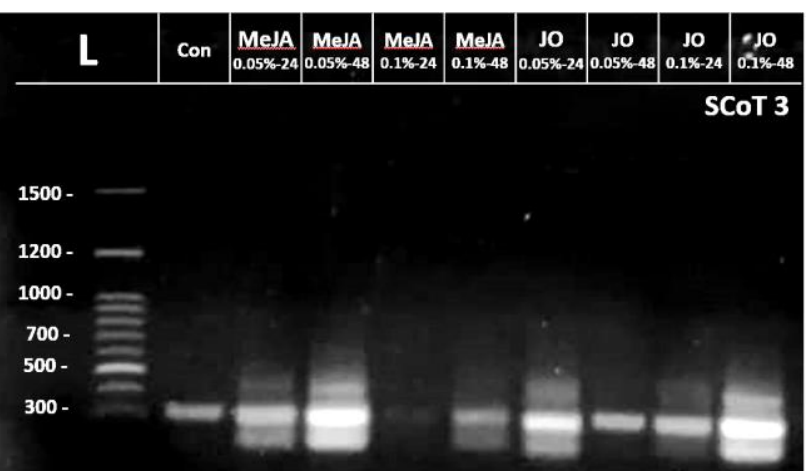

investigate whether MeJA and JO treatments (0.05 and $0.1 \%$ ) at different exposure periods (24 and 48 h) affect gene expression patterns, we used six SCoT primers that target highly expressed genes as described by Sawant et al. (1999) to target amplify cDNA derived from extracted RNA of treated and untreated plants.

Some molecular banding patterns and DNA profiles estimated from cDNA-SCoT technique were shown in Figures (1 and 2). It is evident from Figure 2 that different gene expression patterns between the untreated and treated plants with MeJA and JO were found. This was through targeting 33 scorable TDamplicons with an average of 5.5 TDamplicons/primer, with a product size ranged from 196 and 769 bp. From these TD-amplicons, twelve appeared in the untreated plants and they ranged between 10 to $28 \mathrm{TD}$-amplicons in treated plants. This agreed with Al-Qurainy et al. (2015), who investigated the response of Khalas cultivar of Phoenix dactylifera under different salt stress concentrations, where different amplicons of size were produced using the cDNA-SCoT markers in treated plants whereas were absent in control.

Out of the 33 TD-amplicons targeted by SCoT-primers used in this study, 21 were new transcripts (TDE-amplicons) with $63.6 \%$. While the TDS-amplicons that expression silenced their genes in one or more treatments were 8 from 12 MTDamplicons with $24.4 \%$ from all TD-amplicons. This indicates the high effect of MeJA and JO treatments in expression enhancing of some inactive genes in untreated plants. In addition, to their silenced effect for expression of some active genes targeted by SCoT-primers in untreated plants. Also Wu et al. (2013) employed the cDNA-SCoT approach to detect differential expression of gibberellin-induced genes for sugarcane stalk elongation, which indicated gene upregulation and downregulation.

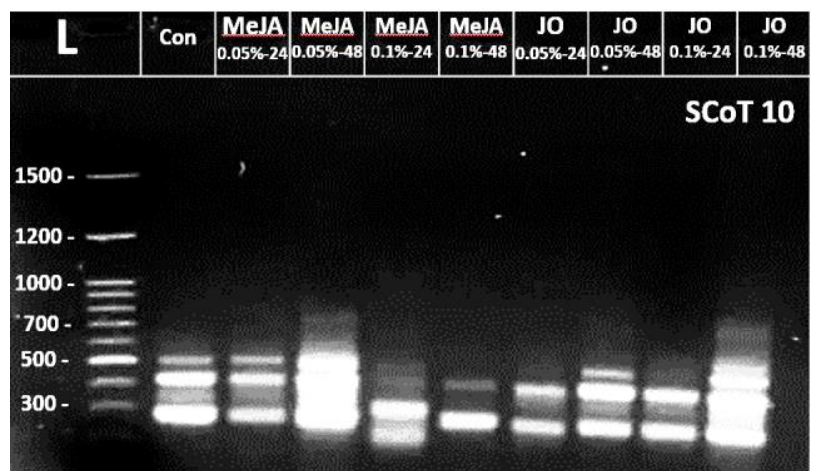

Figure 1. cDNA-SCoT amplification result of SCoT 3 and SCoT 10 after MeJA and JO treatments with two concentrations ( $0.05 \%$ and $0.1 \%$ ) for two periods (24h and $48 \mathrm{~h})$ compared with control in Mentha piprtita. 
Omneya Farouk Abu El-Leel et al., 2021

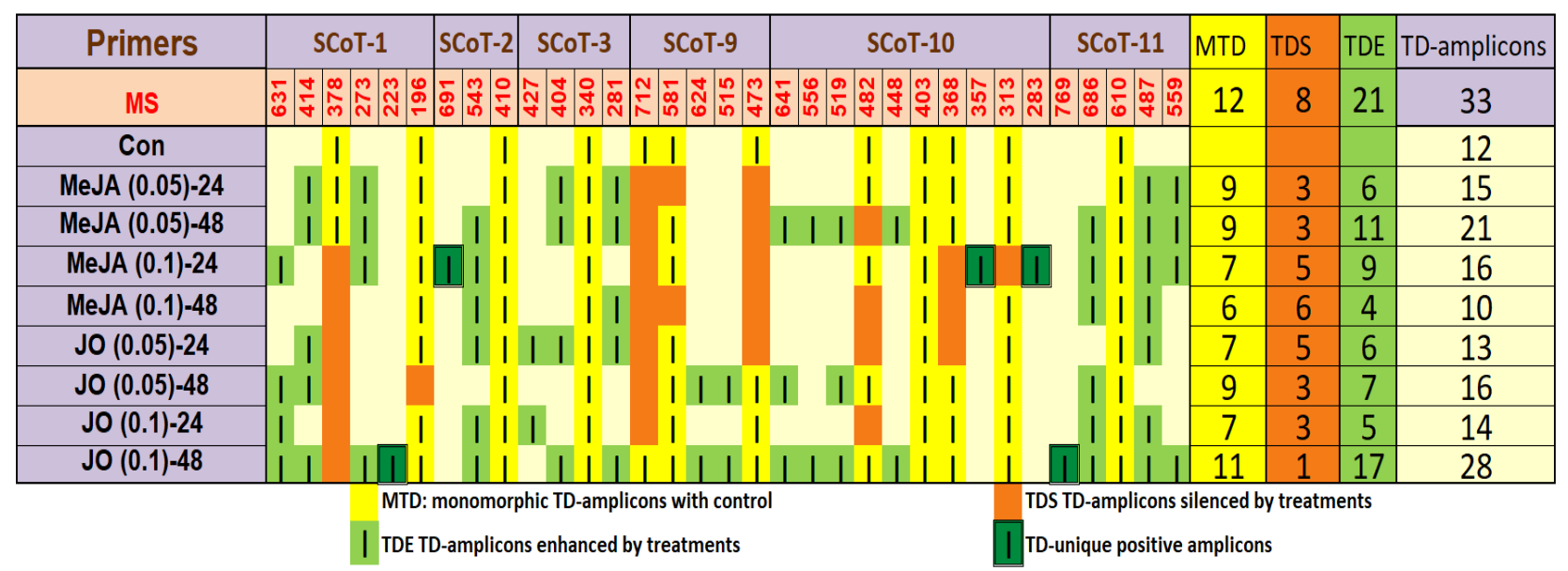

Figure 2. DNA-profile representation of TD-amplicons of cDNA-SCoT molecular marker technique in Mentha piprtita.

TD-amplicons: transcript-derived amplicons TDS: transcript-derived amplicons whose silenced their genes by one or more treatments; TDE: transcript-derived amplicons whose enhanced their genes by one or more treatments; TD monomorphic TD-amplicons with control

On the other hand, Table1 indicated that the SCoT-10 primer showed the highest number of TDamplicons (10) compared with other primers. Moreover, the SCoT-2 primer showed the lowest number of TD-amplicons (3). Where the SCoT-10 primer showed the highest $\mathrm{Rp}$ value (4.44) with polymorphism \% and PIC were 90\% and 0.311, respectively. Also, showed highest TDE-amplicons and TDS-amplicons were 6 and 3, respectively. This illustrating the high informative and discrimination capability of SCoT-10 primer in detection differentially expressed genes among treated and untreated Mentha plants compared to other SCoTprimers used in this study.

Table 1. Molecular data estimated from banding patterns of cDNA-SCoT technique.

\begin{tabular}{|c|c|c|c|c|c|c|c|c|c|}
\hline Primer & & TD-amp & cons & & & & & & \\
\hline Name & $\begin{array}{l}\text { Sequence } \\
\left(5^{\prime} \rightarrow 3^{\prime}\right)\end{array}$ & 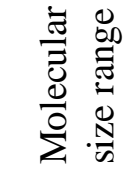 & MTD & TDS & TDE & 苛 & 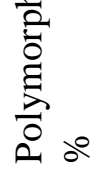 & 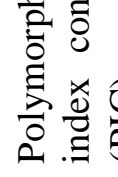 & 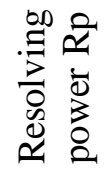 \\
\hline SCoT-1 & CAACAATGGCTACCACCA & 196:631 & 0 & 2 & 4 & 6 & 100.0 & 0.387 & 3.774 \\
\hline SCoT-2 & CAACAATGGCTACCACCC & 410:691 & 1 & 0 & 2 & 3 & 66.7 & 0.214 & 0.888 \\
\hline SCoT-3 & CAACAATGGCTACCACCG & 281:427 & 1 & 0 & 3 & 4 & 75.0 & 0.333 & 2.220 \\
\hline SCoT-9 & CAACAATGGCTACCAGCA & 473:712 & 0 & 3 & 2 & 5 & 100.0 & 0.375 & 2.664 \\
\hline SCoT-10 & CAACAATGGCTACCAGCC & 283:641 & 1 & 3 & 6 & 10 & 90.0 & 0.311 & 4.440 \\
\hline SCoT-11 & AAGCAATGGCTACCACCA & $559: 769$ & 1 & 0 & 4 & 5 & 80.0 & 0.296 & 2.220 \\
\hline
\end{tabular}

The underlines of ATGcodon in the primer sequence were fixed; : TD-amplicons: transcript-derived amplicons TDS: transcript-derived amplicons whose silenced their genes by one or more treatments; TDE: transcript-derived amplicons whose enhanced their genes by one or more treatments; TD monomorphic TD-amplicons with control

According to $\mathrm{HE}$ et al. (2017), silencing of transcripts is caused by gene loss or repress gene expression. Gene loss is irreversible, whereas gene silencing is reversible. In this study, very most transcripts ( 8 TDS from 12 by $66.7 \%$ ) were lost by one or more treatments (Figure 2). MeJA-0.1\% at $48 \mathrm{~h}$ was the highest in gene expression silencing with 6 TDS by $50.0 \%$, while JO- $0.1 \%$ at 48 h was the lowest with TDS by $8.3 \%$ (Figure 3 ). In contrast, MeJA- $0.1 \%$ at $48 \mathrm{~h}$ was the lowest in gene expression enhancing with TDE by $19.0 \%$ (4 out of
21 TDE-amplicons), while JO-0.1\% at $48 \mathrm{~h}$ was the highest with TDS by $81.0 \%$ ( 17 out of 21 TDEamplicons). Additionally, JO- $0.1 \%$ at $48 \mathrm{~h}$ was the highest in total differences of MTD bands-intensity attributing to the control with TDBI MTD $_{\text {by }} 25.7 \%$. Therefore, and through summing percentages of all types of differential TD-amplicons as shown in Figure 3, the highest percentage of differential expression (DE\%) by $115 \%$ was induced by the treatment $\mathrm{JO}-0.1 \%$ at $48 \mathrm{~h}$, followed by $97.4 \%$ induced by MeJA- $0.1 \%$ at $24 \mathrm{~h}$. Moreover, all TD- 


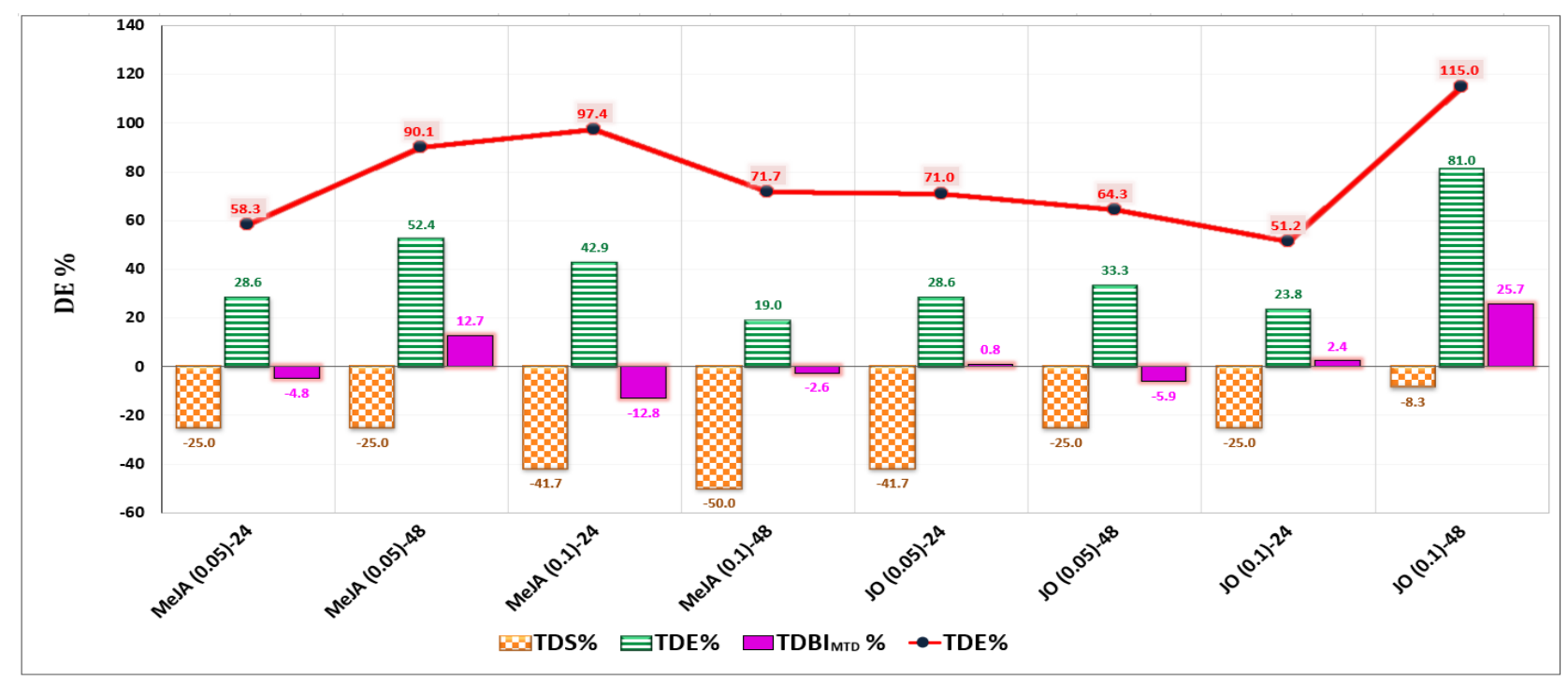

\section{Figure 3. Differential expression \% (DE\%) induced by MeJA and JO treatments attributable to control obtained by summing percentages of all types of differential TD-amplicons}

(TDS\%: \% of TD-amplicons whose silenced their genes by one or more treatments ; TDE\%:TD-amplicons whose enhanced their genes by one or more treatments: $\mathrm{TDBI}_{\mathrm{MTD}} \%: \%$ of total differences of MTD bands -intensity for each treatment attributing to the control).

unique positive amplicons which were five (Figure 2) resulted from transcription enhancement by these two treatments only. Where three of them resulted by MeJA- $0.1 \%$ at $24 \mathrm{~h}$, while two resulted by JO- $0.1 \%$ at $48 \mathrm{~h}$. Indicating the higher influence of treated plants with Jasmine oil with concentration $0.1 \%$ at $48 \mathrm{~h}$ followed by MeJA- $0.1 \%$ at $24 \mathrm{~h}$ on alteration of gene expression patterns.

Moreover, these results confirmed that cDNA-SCoT markers succeeded in detection of variable gene expression patterns between the untreated and treated Mentha plants with MeJA and JO as reported by HE $e t$ al. (2017). Who indicated that the cDNA-SCoT technique could effectively investigate the variations of gene expression in plant species. Also, Abd El-Maksoud et al. (2018) indicated that the cDNA-SCoT markers detected variation in gene expression patterns between untreated and treated wheat seedlings under drought stress. Likewise, Al-Taweel et al. (2019) found the same results between treated stevia plants with different $\mathrm{NaCl}$ concentrations and untreated plants.

\subsection{Semi-quantitative RT-PCR analysis for $\mathrm{mfs}$ gene}

The semi-quantitative RT-PCR was successfully carried out on all cDNA samples representing untreated and treated plants. For each of the mRNA samples, 341-bp fragment of $m f s$-gene and 165-bp fragment of act-gene were specifically amplified. Using act-gene as an internal control or reference gene, the mRNA levels of the above two transcripts were determined among various cDNA samples (Figure 4). As shown in Figure 4, the band intensity of cDNA transcripts of act-1 gene was stable throughout the cDNAsamples at different conditions which confirm the right choice of act-1 gene as a reference gene. Meanwhile, visually varied mfs-transcripts throughout the various cDNA-samples can be attributed to that mfstranscripts were differentially regulated by MeJA and JO treatments.

After converting the visual banding patterns of $m f s$ and act genes into semi-quantified data using GelAnalyzer 2010 software, Figure 5 confirmed the differential expression of $m f s$-transcripts among different cDNA samples through the relative expression levels to the control as $\log 2$ (FC) values. The expression of the $m f s$ gene differed clearly in response to MeJA and JO under 0.05 and $0.1 \%$ concentration at 24 and $48 \mathrm{~h}$ after treatment induction. mfs-gene had the down-regulated gene expression compared with control in leaves samples treated except treated with JO $0.05 \%$ at $48 \mathrm{~h}$ and $\mathrm{JO} 0.1 \%$ at $24 \mathrm{~h}$ which recorded up-regulated gene expression with 0.73 and $0.03 \log 2 \mathrm{FC}$, respectively. Down-regulation of the $m f s$-gene is preferred due to the menthofuran is a highly toxic organic compound in Mentha oil (Anderson et al., 1996). Therefore, the better relative expression levels of $m f s$-gene (which more down-regulated) were recorded for treated with MeJA $0.1 \%$ at $24 \mathrm{~h}$ and JO $0.1 \%$ at $48 \mathrm{~h}$ which were -0.88 and $-0.72 \log 2 \mathrm{FC}$, respectively. Clearly, the expression of the $m f s$-gene was affected by the high percentages of differential expression that inducted by treated with MeJA $0.1 \%$ at $24 \mathrm{~h}$ and 


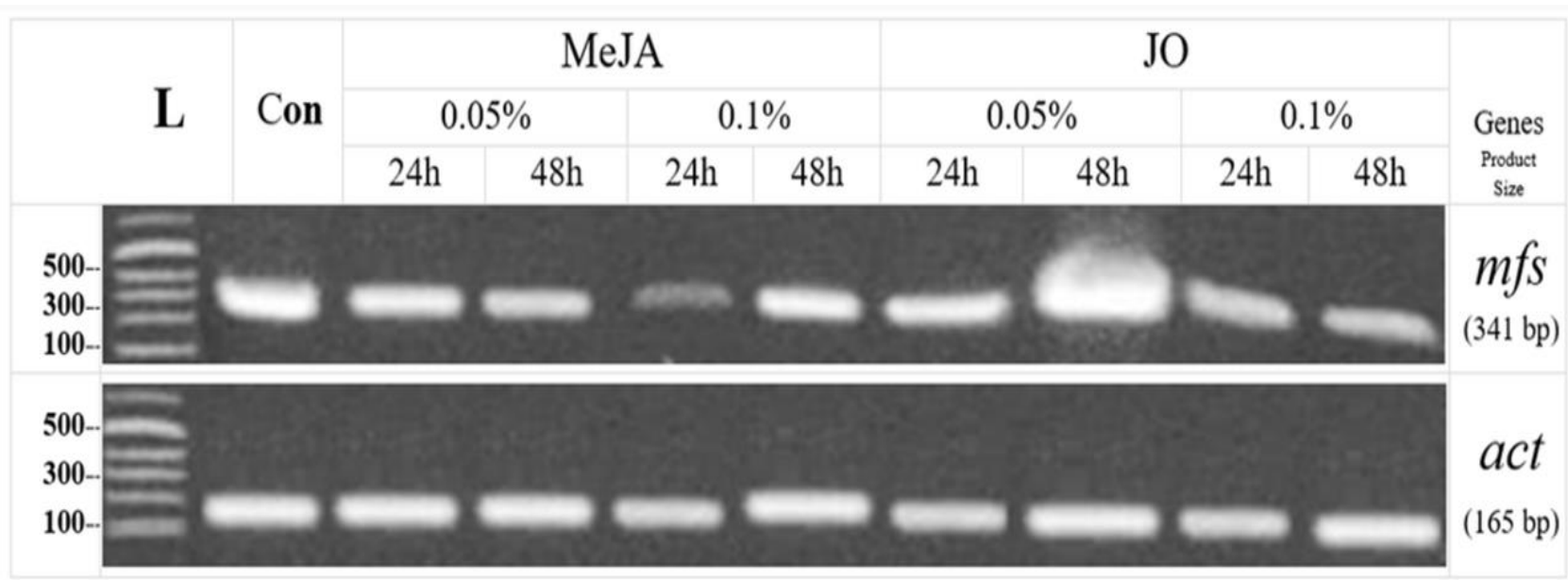

Figure 4. Semi-quantitative RT-PCR of $m f s$ gene after MeJA and JO treatments with two concentrations $(0.05 \%$ and $0.1 \%)$ for two periods $(24 \mathrm{~h}$ and $48 \mathrm{~h})$ compared with control in Mentha piprtita. act gene served a reference gene (internal control) to normalize the $\mathrm{mfs}$ expression levels. $L=$ ladder (100 bp).

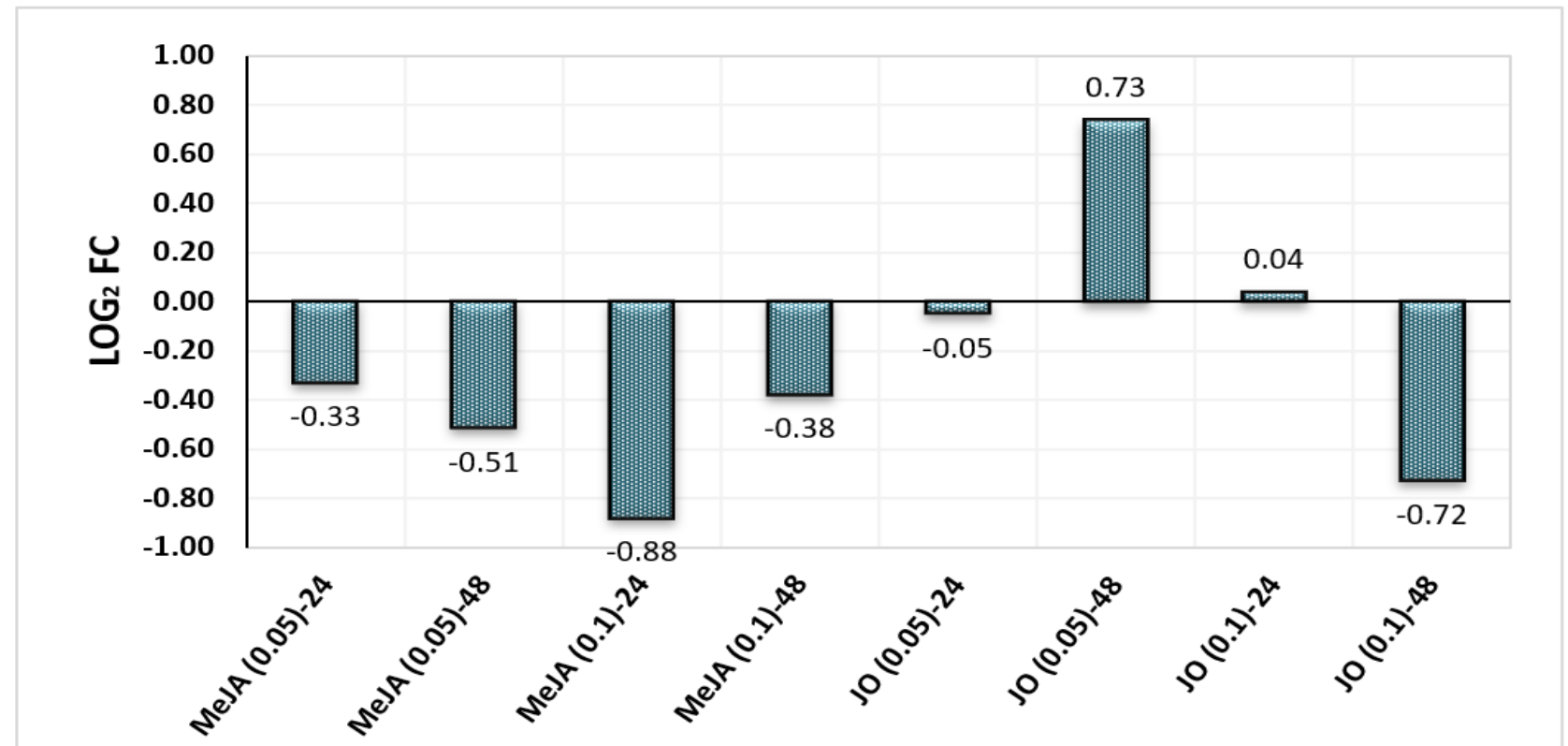

Figure 5. Relative expression levels to the control (Fold change $\log 2$ transformed) using semiquantitative RT-PCR for $m f s$ gene normalized by act. Gene

JO $0.1 \%$ at $48 \mathrm{~h}$. It also turns out that all MeJA treatments affected menthofuran expression, which was also happened by the treatment with low-cost jasmine oil at $0.1 \%$ concentration at $48 \mathrm{~h}$. Thus, we suggest that the $0.1 \%$ jasmine oil spray onto the peppermint plants after $48 \mathrm{~h}$ results in suppression of menthofuran expression, or the accelerated turnover of the $m f s$ message like spraying with MeJA which increases the pharmacological quality of Mentha plant according to Afkar et al. (2013).

\subsection{Volatile oil percentage and composition:}

Data in Figure 6 clearly emphasized that treating Mentha plants with MeJA at $0.1 \%$ and JO at 0.05 or $0.1 \%$ after $48 \mathrm{~h}$ statistically increased volatile oil percentage as compared to control. The highest volatile oil percentages were obtained from these plants applied with $\mathrm{JO}$ at $0.1 \%$ after $48 \mathrm{~h}$ by $1.72 \%$. Similar data had been reported for MeJA where plays a powerful role in inducing the secondary metabolites in different plants (Keinänen et al. 2001). The results of the GLC analysis of the volatile oils of Mentha piperita L were shown in Table1. The identified compounds are ranged from $92.22 \%$ at $0.05 \% \mathrm{MeJA}$ after $24 \mathrm{~h}$ to $95.76 \%$ at $0.1 \%$ MeJA after $48 \mathrm{~h}$. Most compounds were from oxygenated monoterpenes type (10 compounds) and ranged from $77.53 \%$ in $\mathrm{JO}$ at $0.1 \%$ after $48 \mathrm{~h}$ to $83.18 \%$ at $0.1 \%$ MeJA after 48 hours. While the Monoterpene hydrocarbons are represented in 6 compounds and ranged from $8.78 \%$ in $\mathrm{JO}$ at $0.05 \%$ after $48 \mathrm{~h}$ to $14.41 \%$ in $\mathrm{JO}$ at $0.1 \%$ after $48 \mathrm{~h}$. 


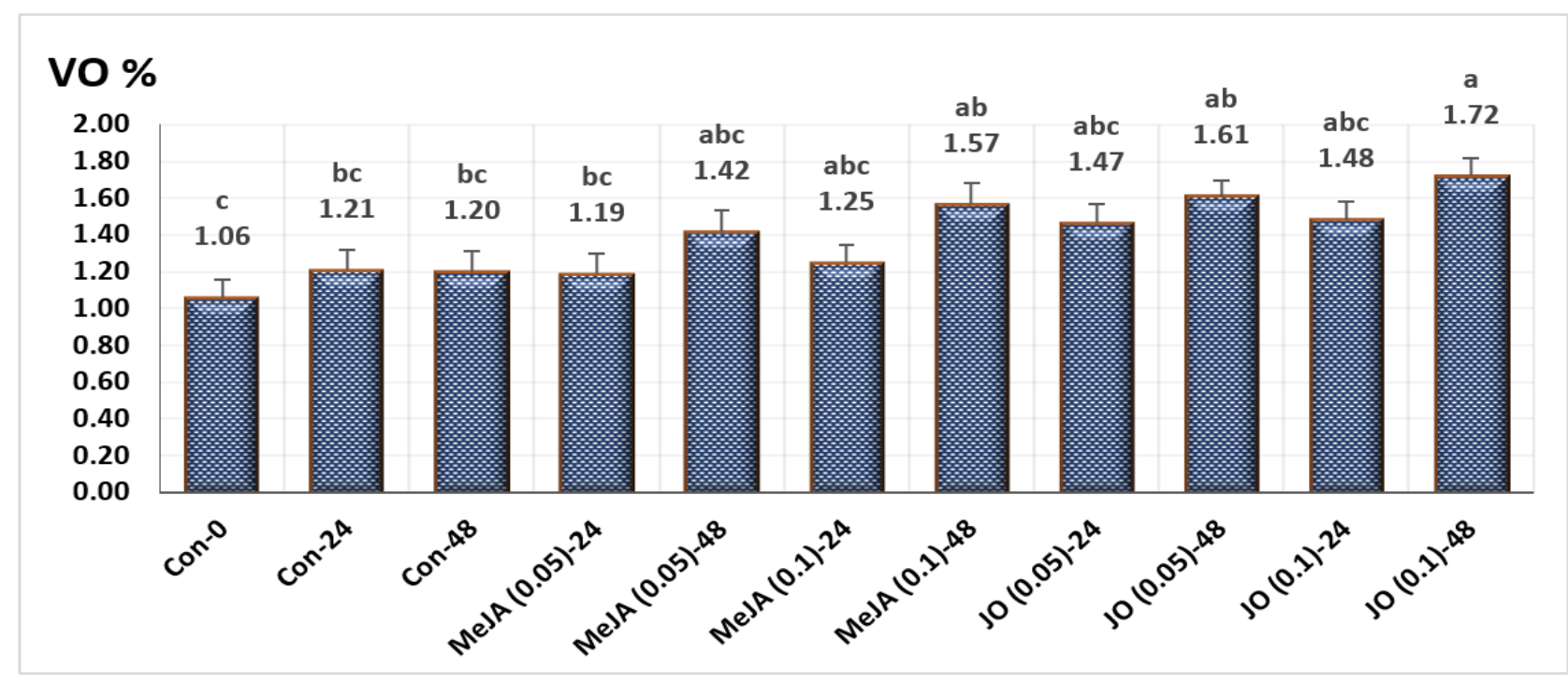

Figure 6. MeJA and JO treatments effect on volatile oil yield percentage (\%) of Mentha piperita L. plant. Different letters indicate significant differences according to Tukey method at $\mathbf{P}<$ 0.05; Results represent mean \pm standard error (SE).

The $\beta$-caryophyllene was the only sesquiterpene hydrocarbons compound estimated and ranged from $0.28 \%$ in MeJA at $0.05 \%$ after $24 \mathrm{~h}$ to $3.69 \%$ in the control. However, there was only one alcohol compound, it was Octanol which ranged from $0.28 \%$ in the control to $1.52 \%$ in $\mathrm{JO}$ at $0.1 \%$ after $48 \mathrm{~h}$. The main constituents of Mentha volatile oils in the untreated plants were Menthol (24.77\%), Isomenthone (18.63\%), Menthone (15.85\%), Isomenthol (11.55\%) and limonene (6.96\%). The increase of menthol levels after the beginning of JO treatment at 0.05 and $0.1 \%$ concentrations and after $48 \mathrm{~h}$ for MeJA at 0.05 and $0.1 \%$ concentrations were resulted in a rapid response for plants to $\mathrm{JO}$ and MeJA and also for their ability of them to stimulate menthol biosynthesis. In this study, the level of the essential oil constituents varied with different concentrations of $\mathrm{JO}$ and $\mathrm{MeJA}$, leading to increases or decreases in the various constituents percentage comparing control plants (Table 1). In this study, we measured the synthesis of volatile oil components in response to varied $\mathrm{JO}$ and $\mathrm{MeJA}$ concentrations (Table 2). The Menthol content in the oil was increased at least 1.05 to 1.49 -fold at $0.05 \%$ and 0.1 $\% \mathrm{JO}$ treatments relative to the control (Figure 7). Menthol amount reduced after treated with MeJA at $0.05 \%$ and $0.1 \%$ after $24 \mathrm{~h}$ but after $48 \mathrm{~h}$ increased compared to the control especially at $0.05 \%$ which observed the highest amount of menthol relative to the control (37.67\%, 1.52-fold).

Menthol is an important major Mentha oil component due to its many important pharmaceutical and industry applications (Kamatou et al., 2013). Besides, Mentha essential oil is associated with some adverse effects (Peixoto et al., 2009). Potentially toxic compounds in Mentha oil are pulegone and menthol. Pulegone and its metabolite menthofuran, are found in peppermint in much smaller proportions. Menthone is a constituent of the essential oils of Mentha. It is structurally related to menthol and industrially used in perfume and cosmetics for its characteristic aromatic and minty odor. However, the excessive inhalation of mentholated preparation may cause reversible nausea, anorexia, cardiac problems, ataxia, and other central nervous system problems (Balakrishnan, 2015). Therefore, the quality of the essential oil from peppermint is described by high menthol and low menthone levels as well as pulegone and menthofuran in very much smaller percentages (Rohloff et al., 2005).

Results in Figure 7 indicated that the Menthone content in the oil was decreased compared to the control from 0.78 and 3.06-fold to 0.69 and 0.99 -fold after $24 \mathrm{~h}$ and $48 \mathrm{~h}$ from spray for MeJA by $0.05 \%$ and $0.1 \%$, respectively. Exactly as we expected because the menthone was a precursor of menthol, which was identified by the previous reports indicating that changes in constituents of essential oil were noticed in many aromatic plants under stress, although these changes in constituents appeared to differ among various plants and the different stresses (Baher et al., 2002; Sangwan et al., 1993). On the contrary, it was the response with JO treatments. Where the Menthone content in the oil was increased compared to the control after $48 \mathrm{~h}$ at $0.05 \%$ and $0.1 \% \mathrm{JO}$ (from 0.73 and 0.77 -fold after $24 \mathrm{~h}$ to 1.07 and 1.85 -fold after $48 \mathrm{~h}$, respectively). 
Table 2. Effect of Methyl Jasmonate (MJ) and Jasmine oil (JO) treatments on volatile oil compositions (\%) of Mentha piperita L. plant.

\begin{tabular}{|c|c|c|c|c|c|c|c|c|c|c|c|}
\hline \multirow{3}{*}{$\begin{array}{l}\text { Peak } \\
\text { No. }\end{array}$} & \multirow{3}{*}{ Components } & \multirow{3}{*}{$\begin{array}{l}\text { Retention } \\
\text { time } \\
\text { (min) }\end{array}$} & \multirow{3}{*}{ Con } & \multicolumn{4}{|c|}{ MeJA } & \multicolumn{4}{|c|}{$\mathrm{JO}$} \\
\hline & & & & \multicolumn{2}{|c|}{$0.05 \%$} & \multicolumn{2}{|c|}{$0.1 \%$} & \multicolumn{2}{|c|}{$0.05 \%$} & \multicolumn{2}{|c|}{$0.1 \%$} \\
\hline & & & & $24 \mathrm{~h}$ & $48 \mathrm{~h}$ & $24 \mathrm{~h}$ & $48 \mathrm{~h}$ & $24 \mathrm{~h}$ & $48 \mathrm{~h}$ & $24 \mathrm{~h}$ & $48 \mathrm{~h}$ \\
\hline 1 & $\alpha$-pinene & 2.62 & 0.93 & 1.11 & 1.02 & 1.2 & 1.18 & 0.93 & 1.01 & 0.87 & 0.56 \\
\hline 2 & $\beta$-pinene & 2.83 & 0.75 & 1.59 & 0.8 & 1.12 & 1.25 & 0.81 & 0.81 & 0.76 & 0.86 \\
\hline 3 & Phellandrene & 2.87 & 0.53 & 0.76 & 0.69 & 0.84 & 1.14 & 0.76 & 0.68 & 0.6 & 2.98 \\
\hline 4 & Limonene & 3.16 & 6.96 & 9.18 & 5.98 & 9.66 & 6.25 & 6.92 & 4.84 & 5.97 & 9.39 \\
\hline 5 & $\gamma$-terpinene & 3.48 & 0.41 & 0.35 & 0.44 & 0.38 & 0.38 & 0.83 & 0.83 & 0.39 & 0.32 \\
\hline 6 & P-cymene & 3.67 & 0.35 & 0.37 & 1.39 & 0.77 & 0.46 & 0.64 & 0.61 & 0.61 & 0.3 \\
\hline 7 & 1,8-cineol & 3.21 & 1.79 & 2.15 & 1.73 & 4.58 & 3.19 & 1.39 & 1.37 & 1.14 & 1.88 \\
\hline 8 & L-Menthone & 3.85 & 0.44 & 0.43 & 1.32 & 1.32 & 0.61 & 1.76 & 0.59 & 0.82 & 1.19 \\
\hline 9 & Menthyl acetate & 4.24 & 2.13 & 2.77 & 1.09 & 1.88 & 0.95 & 2.3 & 2.69 & 1.35 & 2.44 \\
\hline 10 & Menthol & 4.33 & 24.77 & 23.27 & 37.67 & 11.44 & 28.19 & 25.9 & 36.93 & 36.35 & 29.88 \\
\hline 11 & Isomenthone & 4.44 & 18.63 & 26.62 & 11.54 & 1.41 & 21.35 & 20.97 & 9.71 & 15.36 & 3.61 \\
\hline 12 & Menthone & 4.53 & 15.35 & 11.97 & 10.55 & 47.03 & 15.24 & 11.27 & 16.44 & 11.83 & 28.41 \\
\hline 13 & Isomenthol & 4.59 & 11.55 & 8.28 & 9.93 & 3.56 & 10.26 & 11.79 & 11.73 & 12.53 & 4.69 \\
\hline 14 & Neoisomenthol & 4.66 & 1.35 & 1.76 & 1.49 & 2.8 & 1.59 & 1.25 & 1.74 & 1.95 & 3.83 \\
\hline 15 & Linalool & 4.81 & 1.72 & 0.5 & 0.73 & 1.23 & 1.47 & 1.89 & 1.27 & 1.16 & 1.3 \\
\hline 16 & Carvone & 5.38 & 1.78 & 0.31 & 1.76 & 1.16 & 0.33 & 1.99 & 0.48 & 0.41 & 0.3 \\
\hline 17 & $\beta$-caryophyllene & 5.37 & 3.69 & 0.28 & 3.56 & 1.21 & 0.87 & 2.66 & 0.96 & 0.65 & 0.44 \\
\hline 18 & Octanol & 3.97 & 0.28 & 0.52 & 1.1 & 0.89 & 1.05 & 0.95 & 1.4 & 0.6 & 1.52 \\
\hline \multicolumn{3}{|c|}{ Total Identified } & 93.41 & 92.22 & 92.79 & 92.48 & 95.76 & 95.01 & 94.09 & 93.35 & 93.9 \\
\hline \multicolumn{3}{|c|}{ Unknown } & 6.59 & 7.78 & 7.21 & 7.52 & 4.24 & 4.99 & 5.91 & 6.65 & 6.1 \\
\hline \multicolumn{3}{|c|}{ (1:6) Monoterpene hydrocarbons } & 9.93 & 13.36 & 10.32 & 13.97 & 10.66 & 10.89 & 8.78 & 9.2 & 14.41 \\
\hline \multicolumn{3}{|c|}{ (7:16) Oxygenated monoterpenes } & 79.51 & 78.06 & 77.81 & 76.41 & 83.18 & 80.51 & 82.95 & 82.9 & 77.53 \\
\hline \multirow{2}{*}{\multicolumn{3}{|c|}{$\begin{array}{l}\text { (17) Sesquiterpene hydrocarbons } \\
\text { (18) Alcohol }\end{array}$}} & 3.69 & 0.28 & 3.56 & 1.21 & 0.87 & 2.66 & 0.96 & 0.65 & 0.44 \\
\hline & & & 0.28 & 0.52 & 1.1 & 0.89 & 1.05 & 0.95 & 1.4 & 0.6 & 1.52 \\
\hline
\end{tabular}

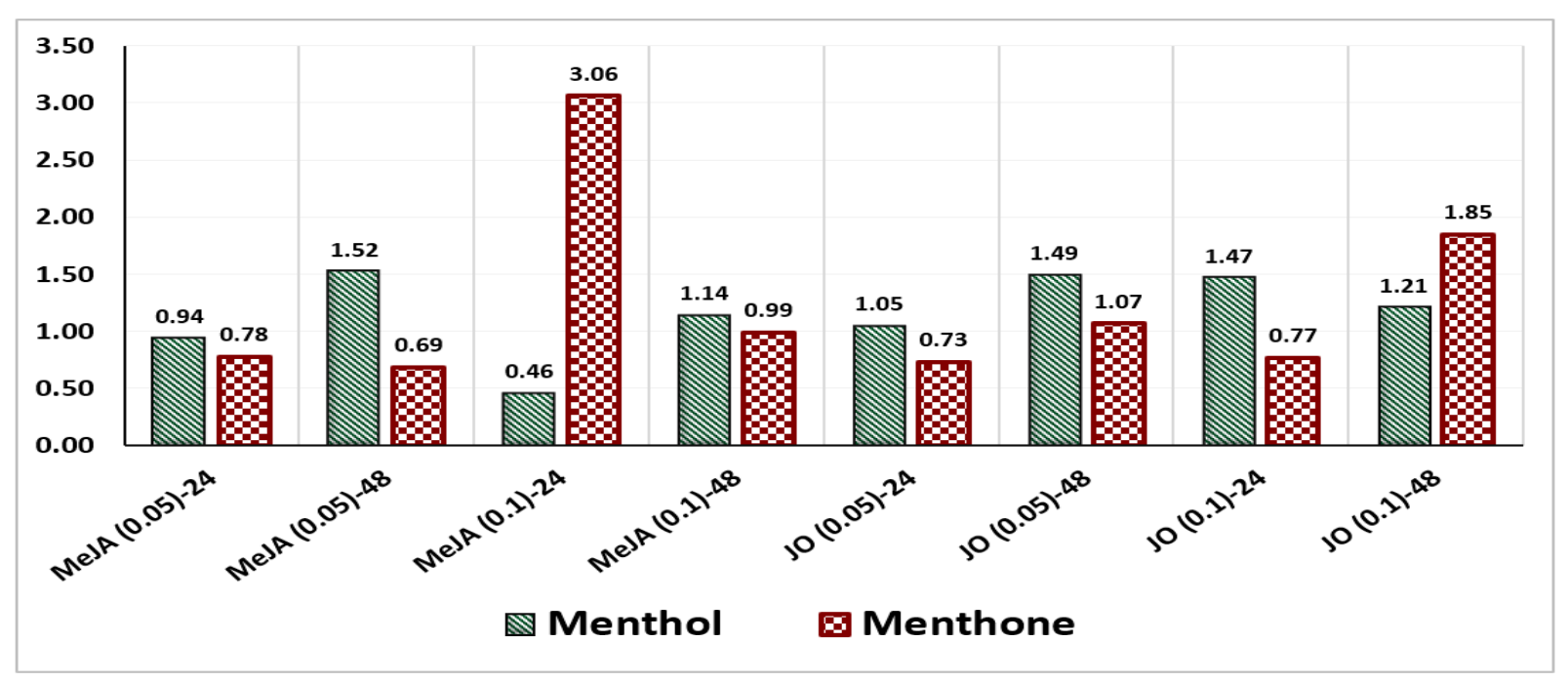

Figure 7. Menthol and Menthone content in the oil relative to the control in response to treatment with JO and MeJA.

This indicates that the treatment with $\mathrm{JO}$ requires the collection of samples to oil extract within $24 \mathrm{~h}$ to prevent further accumulation of Menthone, which is not required by treatment with MeJA. The lowest amount of menthone was after
$48 \mathrm{~h}$ from spray for MeJA by $0.05 \%$ and after $24 \mathrm{~h}$ from spray for JO by $0.1 \%$.

Our results represented that, application of MeJA and JO elicit menthol and as a secondary metabolite. Also, revealed that, the highest percentages of menthol with the lowest percentages 
of the menthone and low level of menthofuran gene expression compared to the control, were found after $48 \mathrm{~h}$ from applying the spray for MeJA by $0.05 \%$ and after $24 \mathrm{~h}$ from applying the spray for JO by $0.1 \%$. Previous research has shown that exogenous MeJA treatment can enhance the concentration of secondary metabolites in plants including Ocimum basilicum, Nicotiana attenuata, and Rubus carolinianus. (Kim et al., 2007).

\subsection{Vegetative traits:}

At the end of the experiment, five vegetative traits were estimated for untreated and treated peppermint plants (Figure 8), to assess the vegetative growth under the treatment of MeJA and
JO. Where, the results presented in Figure 8 showed that there were no significant differences among all treatments in all the estimated vegetative traits. Likewise, between treated and untreated plants, except between treated plants with MeJA by $0.05 \%$ and untreated plants for leaf area/plant $\left(\mathrm{cm}^{2}\right)$ and number of leaves/plant. Where the treated plants showed a significant increase compared to the control with an average of 264 leaves per plant and an average leaf area of $3333 \mathrm{~cm}^{2}$. In addition, most of the MeJA and JO treatments induced higher vegetative growth activity than the untreated plants but were not significantly.

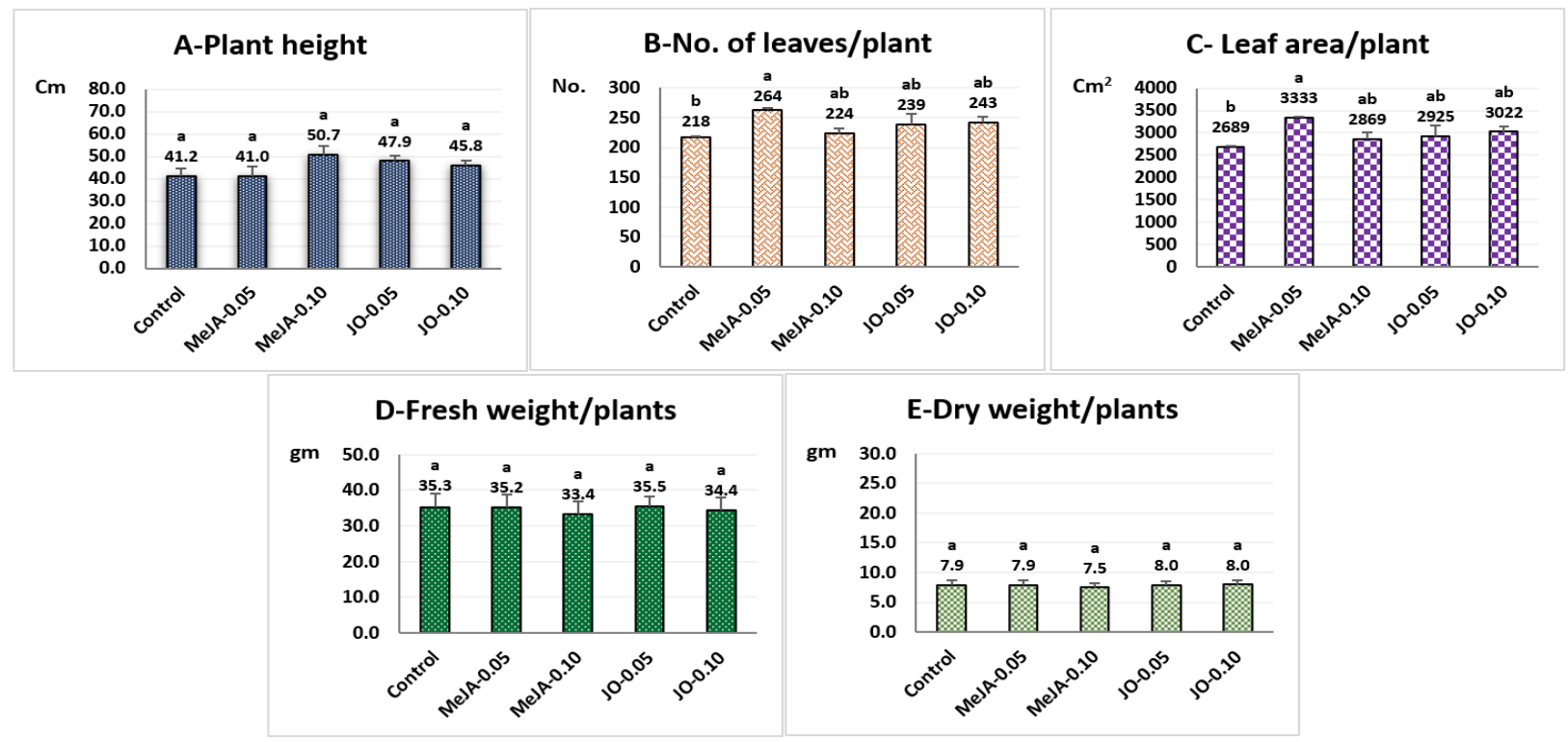

Figure 8. Effect of MeJA and JO treatments on Vegetative traits of Mentha piperita L. plant. Different letters indicate significant differences according to Tukey method at $\mathbf{P}<0.05$; Results represent mean \pm standard error $(\mathrm{SE})$.

Finally, the vegetative traits results concluded that application of exogenous Methyl Jasmonate (MeJA) and Jasmine oil (JO) treatments enhanced the vegetative growth terms plants but were not significantly. These results are in accordance to (Rahimi et al., 2013) on cumin plants reporting that all concentrations of MeJA had no signific ant effect on growth and yield parameters.

\section{CONCLUSION}

In general, exogenously foliar application of Methyl Jasmonate (MeJA) and Jasmine oil (JO) treatments induced alteration of gene expression patterns which was detected by cDNA-SCoT with high informative and discrimination capability. Also, mfs-transcripts were differentially regulated by MeJA and JO treatments. Our results revealed that high level of volatile oil, highest percentages of menthol with the lowest percentages of the menthone, low level of menthofuran gene expression and good vegetative grow th compared to the control were found with exogenously foliar application of MeJA by $0.05 \%$ after $48 \mathrm{~h}$ and JO by $0.1 \%$ after 24 $\mathrm{h}$, which increases the pharmacological quality of Mentha plant. This indicates the possibility of using JO (Low-cost) after further study as a stimulant for the activity of menthol production with high quality as a cheaper alternative to exogenously foliar application of MeJA.

- Author Contributions: Conceptualization and methodology, all authors; applic ation of treatments and determination of volatile oil composition, Omneya Farouk Abu El-Leel, S. Y. Mohamed; Molecular assessment, M. H. Abd EL-Aziz, S. Y. Mohamed and Noha A. Sukar; writing-original draft preparation, M. H. Abd EL-Aziz and Omneya Farouk Abu El-Leel; and Noha A. 
Sukar; writing — review and editing, M. H. Abd EL-Aziz, S. Y. Mohamed and Noha A. Sukar; All authors have read and agreed to the published version of the manuscript.

- Conflicts of Interest: The authors declare no conflict of interest.

- Ethical approval: Not applicable

\section{REFERENCES}

Abd El-Aziz MH, Mohamed SY, Hadeer Magwaid E (2019). Molecular and phytochemical assessment for some seedy strains of Alamar apricot rootstock under salinity stress. Egyptian Journal of Basic and Applied Sciences, 6 (1), 173-186. https://doi.org/10.1080/2314808X.2019.1690358

Abd EL-maksoud RM, Ibrahim SD, Faheem MM, Amer MN (2018). Analysis of differential gene expression in response to drought stress in wheat (Triticum aestivum L.) using cDNA-SCoT. Egyptian Journal of Genetics And Cytology, 47(2), 263-277. Web Site (www.esg.net.eg)

Adhikari S, Saha S, Bandyopadhyay TK, Ghosh P (2015). Efficiency of ISSR marker for characterization of Cymbopogon germplasms and their suitability in molecular barcoding. Plant Systematic and Evalouation, 301, 439-450.

Afkar S, Karimzadeh G, Jalali-Javaran M, Sharif M, Behmanesh M (2013). Influence of Methyl Jasmonate on Menthol Production and Gene Expression in Peppermint (Mentha $x$ piperita L.). Journal of Medicinal Plants and By-products, 1, 7582.

AL-Janabi AS, AL-rawi TK (2018). Effect of irrigation times and termination on gene expression of OeDGAT1, OeFAD2.1, AND OeFAD6 and oil quality and qoantity in olive cultivars. SABRAO Journal of Breeding and Genetics, 50 (3), 329-343. DOI 10.1007/s00606-014-1084-y

AL-Qurainy F, Khan S, Nadeem M, Tarroum M (2015). SCoT marker for the assessment of genetic diversity in Saudi Arabian date palm cultivars. Pak. J. Bot., 47(2), 637-643.

AL-Taweel S, Abdel-Aziz R, Rabea K, Khaled K (2019). Studying cDNA SCoT in response to salinity stress in Stevia rebaudiana beryoni. SABRAO journal of breeding and genetics, 51(3), 281-294.

Anderson IB, Mullen WH, Meeker JE, Khojasteh-BakhtSC, Oish S, Nelson SD et al (1996). Pennyroyal toxicity: measurement of toxic metabolite levels in two cases and review of the literature. Annals Internal Medicine, 124(8), 726734. DOI: 10.7326/0003-4819-124-8-19960415000004

Baher ZF, Mirza M, Ghorbanli M, Rezaii MB (2002). The influence of $w$ ater stress on plant height, herbal and essential oil yield and composition in
Satureja hortensis L. Flavour and fragrance journal, 17, 275-277.

Balakrishnan A (2015). Therapeutic uses of peppermint $-\mathrm{A}$ review. Journal of Pharmaceutical Sciences and Research, 7(7), 474-476.

Banthorpe DV (1996). Mentha Species (Mints): In Vitro Culture and Production of Lower Terpenoids and Pigments. In: Bajaj Y.P.S. (ed) Medicinal and Aromatic Plants IX. Biotechnology in Agriculture and Forestry, (Vol. 37). Springer, Berlin, Heidelberg. https://doi.org/10.1007/978-3-662-08618-6_13

Baser KH, Kurk cuoglu M (1999). Essential oils of Mentha species from Northern Turkey. J. Essent. Oil Res., 11, 579-588. DOI: 10.1002/ffj.1097

British Pharmacopeia (1963). Determination of Volatile Oil in Drugs. The Pharamaceutical Press, London.

Bunzen JN, Guchard J, Labbe P, Sperinnet PJ, Trenchant J (1969). Practical Manual of Gas Chromatography. J. Trenchant Ed., El-Seiver Publ. Comp., Amsterdam, London.

Chakraborty A, Chattopadhyay S (2008). Stimulation of Menthol Production in Mentha piperita Cell Culture. In Vitro Cellular \& Developmental Biology. Plant, 44(6), 518-524. http://ww w.jstor.org/stable/20461755

Chang PF, Narasimhan ML, Hasegawa PM, Bressan RA (1993). Quantitative mRNA-PCR for expression analysis of low-Abundance transcripts. Plant Molecular Biology Reporter, 11 (3), 237-248.

Chen MH, Zhang BQ, Song XP, Chen H, Yang LT, LI YR et al (2013). cDNA- SCoT analysis of differentially expressed genes in sugarcane induced by Leifsoniaxyli subsp. Xyli. Acta Agronomica Sinica, $\quad 39 \quad$ (6), $1119-1126$. DOI: 10.3724/SP.J.1006.2013.01119

Choi D, Bostock RM, Avdiushko S, Hildebrand DF (1994). Lipid-derived signals that discriminate wound- and pathogen-responsive isoprenoid pathways in plants: methyl jasmonate and the fungal elicitor arachidonic acid induce different 3-hydroxy3-methylglutaryl-coenzyme A reductase genes and antimicrobial isoprenoida in Solanum tuberosum L. Proc Natl Acad Sci USA, 91(6), 2329-2333. DOI: 10.1073/pnas.91.6.2329.

Choi DW, Jung J, Ha YI, Park HW, In DS, Chung HJ, et al (2005). Analysis of transcripts in methyl jasmonate-treated ginseng hairy roots to identify genes involved in the biosynthesis of ginsenosides and other secondary metabolites. Plant Cell Reports, 23, 557-566. DOI 10.1007/s00299004-0845-4

Collard BC, Mackill DJ (2009). Start Codon Targeted (SCoT) Polymorphism: A Simple, Novel DNA Marker Technique for Generating GeneTargeted Markers in Plants. Plant Molecular Biology 
Reporter, 27(1), 86-93. DOI: 10.1007/s11105-0080060-5

Eccles R (1994). Menthol and related cooling compounds. J Pharm Pharmacol, 46(8), 618-630. DOI: $10.1111 / j .2042-7158.1994 . t b 03871 . x$

Fahlen A, Welander M, Wennersten R (1997). Effects of light temperature regimes on plant growth and essential oil yield of selected aromatic plants. J Sci Food Agric, 73, 111-119.

Faldt J, Martin D, Miller B, Rawat S, Bohlmann J (2003). Traumatic resin defense in Norway spruce (Picea abies): methyl jasmonate-induced terpene synthase gene expression, and cDNA cloning and functional characterization of (+)-3-carene synthase. Plant Mol Biol, 51(1), 119-133. DOI: $10.1023 / \mathrm{a}: 1020714403780$

Farmer EE, Ryan CA (1990). Interplant communication: airborne methyl jasmonate induces synthesis of proteinase inhibitors in plant leaves. Proc Natl Acad Sci U S A., 87(19), 7713-7716. DOI: 10.1073/pnas.87.19.7713

Fleming AJ, Manzara T, Gruissem W, Kuhlemeier C (1996). Fluorescent imaging of GUS activity and RT-PCR analysis of gene expression in the shoot apical meristem. Plant J., 10(4), 745-754. DOI: 10.1046/j.1365-313x.1996.10040745.x

Galeotti N, Ghelardini C, Mannelli L, Mazzanti G, Baghiroli L, Bartolini A (2001). Local anaesthetic activity of (+)- and (-)-menthol. Planta Med., 67(2), 174-176. DOI: 10.1055/s-2001-11515 Gorji AM, Poczai P, Polgar Z, Taller J (2011). Efficiency of Arbitrarily Amplified Dominant Markers (SCOT, ISSR and RAPD) for Diagnostic Fingerprinting in Tetraploid Potato. American Journal of Potato Research, 88, 226-237. https://doi.org/10.1007/s12230-011-9187-2

HE Lq, Tang Rh, Jiang J, Xiong Fq, Huang Zp, Wu Hn et al (2017). Rapid gene expression change in a novel synthesized allopolyploid population of cultivated peanut $\times$ Arachis doigoi cross by cDNASCoT and HFO-TAG technique. Journal of Integrative Agriculture, 16(5), 1093-1102. https://doi.org/10.1016/S2095-3119(16)61462-4

Hefner J, Ketchum RE, Croteau R (1998). Cloning and functional expression of a cDNA encoding geranylgeranyl diphosphate synthase from Taxus Canadensis and assessment of the role of this prenyltransferase in cells induced for taxol production. Archives of Biochemistry and Biophysics, 360, 62-74.

Hoftman E (1967). Chromatography. Reinhold Publ. Corp. 2nd Ed., 208-515.

Inoue F, Sugiura H, Tabuchi A, Karasawa De, Minami M (2003). Plant Regeneration of Peppermint, Mentha plperlta from the Hairy Roots Generated from Microsegment Infected with Agrobacterium rhizogenes. Plant Biotechnology,
20(2),

169 -

172.

DOI:

10.5511/plantbiotechnology.20.169

Kamatou GP, Vermaak I, Viljoen AM, Lawrence BM (2013). Menthol: A simple monoterpene with remarkable biological properties. Phytochemistry, 96 ,

$15-25$.

https://doi.org/10.1016/j.phytochem.2013.08.005

Keinanen M, Oldham NJ, Baldwin IT (2001). Rapid HPLC Screening of Jasmonate-Induced Increases in Tobacco Alkaloids, Phenolics, and Diterpene Glycosides in Nicotianaattenuata. J. Agric. Food Chem., 49(8), 3553-3558. https://doi.org/10.1021/jf010200+

Kim EH, Kim YS, Park SH, Koo YJ, Choi YD, Chung YY et al (2009). Methyl Jasmonate Reduces Grain Yield by Mediating Stress Signals to Alter Spikelet Development in Rice. Plant Physiology, 149 ,

$1751-1760$

http://dx.doi.org/10.1104/pp.108.134684

Kim HJ, Fonseca JM, Choi JH, Kubota C (2007). Effect of methyl jasmonate on phenolic compounds and carotenoids of romaine lettuce (Lactuca sativa L.). J Agric Food Chem, 55(25), 10366-10372. DOI: $10.1021 / \mathrm{jf071927m}$

Kjonaas R, Croteau R (1983). Demonstration that limonene is the first cyclic intermediate in the biosynthesis of oxygenated p-menthane monoterpenes in Mentha piperita and other Mentha species. Arch Biochem Biophys, 220(1), 79-89. DOI: 10.1016/0003-9861(83)90389-2

Kokkini S (1991). Chemical Races Within the Genus Mentha L.. In: Linskens H.F., Jackson J.F. (eds) Essential Oils and Waxes. Modern Methods of Plant Analysis, (Vol. 12). Springer, Berlin, Heidelberg. https://doi.org/10.1007/978-3-64284023-4_4

Luo C, He XH, Hu Y, Yu Hx, Ou SJ, Fang ZB (2014). Oligo-dT anchored cDNA-SCoT: a novel differential display method for analyzing differential gene expression in response to several stress treatments in mango (Mangifera indica L.). Gene, 548(2), 182-189.

https://doi.org/10.1016/j.gene.2014.07.024

Macieje wsk a BD, Kesy J, Zielinska M, Kopce wicz J (2004). Jasmonates inhibit flowering in short-day plant Pharbitis nil. Plant Grow th Regulation, 43, 1-8. http://dx.doi.org/10.1023/B:GROW.0000038241.007 71

Marone M, Mozzetti S, Ritis DD, Pierelli L, Scambia G (2001). Semiquantitative RT-PCR analysis to assess the expression levels of multiple transcripts from the same sample. Biol Proced Online, 3, 19-25.

Martiansyah I, Amanah DM, Putranto RA (2018). Semi-quantitative RT-PCR analysis of transcripts encoding protease inhibitor in Hevea brasiliensis Muell. Arg latex. Earth and Environmental Science 
183. https://doi.org/10.1088/1755-

1315/183/1/012004

Martin D, Tholl D, Gershenzon J, Bohlmann, J (2002). Methyl jasmonate induces traumatic resin ducts, terpenoid resin biosynthesis, and terpenoid accumulation in developing xylem of Norw ay spruce stems. Plant Physiol, 129(3), 1003-1018. DOI: 10.1104/pp.011001

Miranda $H$ (2011). Stress response in the cyanobacterium Synechocystis sp. PCC 6803. Department of Chemistry, Umea University, Sweden. Doctoral Thesis.

Munns R, Tester M(2008). Mechanisms of salinity tolerance. Annu Rev Plant Biol, 59, 651-681. DOI: 10.1146/annurev.arplant.59.032607.092911

Patel T, Ishiuji Y, Yosipovitch G (2007). Menthol: a refreshing look at this ancient compound. $\mathrm{J}$ Am Acad Dermatol, 57(5), 873-878.

Peixoto I, Furlanetti V, Anibal P, Duarte M, Höfling J (2009). Potential pharmacological and toxicological basis of. Rev Ciênc Farm Básica Apl, 30(3), 235-239.

Prevost A, Wilkinson MJ (1999). A new system of comparing PCR primers applied to ISSR fingerprinting of potato cultivars. Theor Appl Genet, 98, 107-112.

Prins CL, Vieira IJ, Freitas SP (2010). Growth regulators and essential oil production. Brazilian Journal of Plant Physiology, 22, 91-102.

Pushpangadan P, Tewari SK (2006). Handbook of Herbs and Spices. Woodhead Pblishing Limited Cambridge, England and CRC Press New York Washington. (Vol.3). 460-481.

Rahimi A, Rokhzadi A, Amini S, Karami E (2013). Effect of salicylic acid and methyl jasmonate on growth and secondary metabolites in Cuminum cyminum L. Journal of Biodiversity and Environmental Sciences, 3(12), 140-149.

Rahimi Y, Taleei A, Ranjbar M (2017). Changes in the expression of key genes involved in the biosynthesis of menthol and menthofuran in Mentha piperita L. under drought stress. Acta Physiologiae Plantarum, 39, 203. DOI 10.1007/s11738-017-2502$\mathrm{X}$

Ramanjulu S, Bartels D (2002). Drought- and desiccation-induced modulation of gene expression in plants. Plant Cell Environ., 25(2), 141-151. DOI: 10.1046/j.0016-8025.2001.00764.x

Rohloff J (1999). Monoterpene composition of essential oil from peppermint (Mentha x piperita L.) with regard to leaf position using solid-phase microextraction and gas chromatography/mass spectrometry analysis. J Agric Food Chem, 47(9), 3782-3786. DOI: 10.1021/jf981310s
Rohloff J, Dragland S, Mordal R, Iversen TH (2005). Effect of harvest time and drying method on biomass production, essential oil yield, and quality of peppermint (Mentha $x$ piperita L.). Journal of Agricultural and Food Chemistry, 53(10), 41434148. DOI: $10.1021 /$ jf047998s

Sangwan R, Farooqi A, Bansal R, Singh-Sangwan $\mathbf{N}$ (1993). Interspecific variation in physiologic al and metabolic responses of five species of Cymbopogon to water stress. J. Plant, 142, 618-622

Sawant SV, Singh PK, Gupta SK, Madnala R, Tuli $R$ (1999). Conserved nucleotide sequences in highly expressed genes in plants. Journal of Genetics, 78, 123-131.

Souza A, Souza D, Sanabani S, Giorgi R, Bendit I (2009). The performance of semi-quantitative differential PCR is similar to that of real-time PCR for the detection of the MYCN gene in neuroblastomas. Braz J Med Biol Res, 42(9), 791795.

Staswick PE, Howell WS (1992). Methyl jasmonate inhibition of root growth and induction of a leaf protein are decreased in an Arabidopsis thaliana mutant. Proc Natl Acad Sci USA, 89(15), 68376840. DOI: 10.1073/pnas.89.15.6837

Tang C, Qi J, Li H, Zhang C, Wang Y (2007). A convenient and efficient protocol for isolating highquality RNA from latex of Hevea brasiliensis (para rubber tree). J Biochem Biophys Methods, 70(5), 749-754. DOI: 10.1016/j.jbbm.2007.04.002.

Thomassen D, Knebel N, Slattery JT, McClanahan RH, Nelson SD (1992). Reactive intermediates in the oxidation of menthofuran by cytochromes P-450. Chemical Research Toxicologyl, 5(1), 123-130. DOI: 10.1021/tx00025a021

Warabieda W, Olszak RW (2010). Effect of exogenous methyl jasmonate on numerical grow th of the population of the two-spotted spider mite (Tetranychus urticae Koch.) on strawberry plants and young apple trees. Journal of Plant Protection Research, 50(4), 541-544. DOI: https://doi.org/10.2478/v10045-010-0089-y

Wu JM, Li YR, Yang LT, Fang FX, Song Hz, Tang HQ et al (2013). cDNA-SCoT: A novel rapid method for analysis of gene differential expression in sugarcane and other plants. Australian Journal of Crop Science, 7(5), 659-664.

Youssef K, Sanzani SM, Ligorio A, Ippolito A, Terry LA (2014). Sodium carbonate and bicarbonate treatments induce resistance to postharvest green mould on citrus fruit. Postharvest Biology and Technology, 87, 61-69. https:// doi .org /10 .1016/j. postharvbio.2013.08.006 


\title{
الملخص العربي
}

\section{تأثير زيت الياسمين والميثيل جاسمونيث على التعبير الجيني وإنتاج المنثول في النعناع}

\author{
أمنية فاروق أبو الليل' وسيد يوسف محمد` ونها الاسوقي عبد السميع سكرّ ومحمد حسن عبد العزيز؛
}

$$
\begin{aligned}
& \text { 'قسم النباتات الطبية والعطرية - معهد بحوث البسانين - مركز البحوث الزراعية - الجيزه } \\
& \text { זَقسم الفاكهه منساقطه الاوراق - معهد بحوث البساتين - مركز البحوث الزراعية - الجيزه }
\end{aligned}
$$

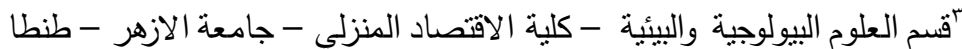

$$
\begin{aligned}
& \text { قُقم الوراثة - كلية الزراعة - جامعة المنصورة العئة }
\end{aligned}
$$

النعناع هو المصدر الرئيسي للمنثول والذى بستخدم في العديد من الأغراض التجارية والصيدلاثية الهامة. لتعزيز إنتاج المنثول ، هدفت الدراسة إلى تقييم تأثير التطبيق الورقي الخارجي برش مخففات زيت الياسمين والميثيل جاسمونيت بنسبة هـ... و ا.. ٪ على التعبير الجيني ، وإنتاج الزيوت الطيارة ومكوناتها خاصة المنتول في النعناع. حيث أدت معاملات الميثيل جاسمونيت وزيت الياسمين إلى تغيير أنماط التعبير الجيني التي تم تقليرها بواسطة تقنية CDNA-SCoT مع قدرة تعريف وتمييز مرتفعة للتناين على المستوى الجزيئي. حيث استهدفت

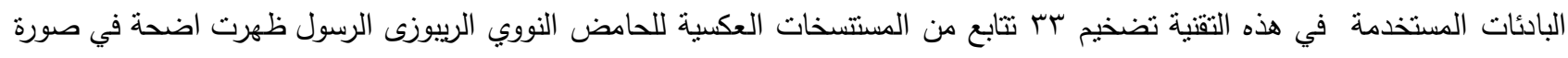
حزم على جل التفريد الكهربى ، كان / منها حزمة جليدة ومنتوعة بين المعاملات ـ وقد أوضح تحليل أنماط التعيير الجينى المتغايروالمقارن

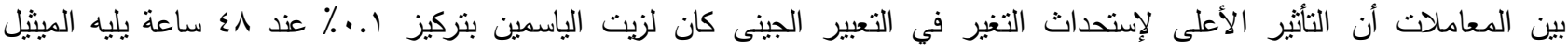

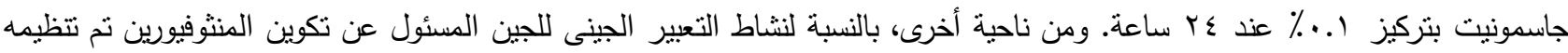
بشكل متغاير بواسطة معاملات الميثيل جاسمونيت وزيت الياسمين. وبشكل عام ، كثفت النتائج عن مستوى مرتفع من الزيت المتطاير ،

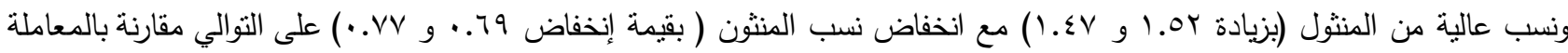

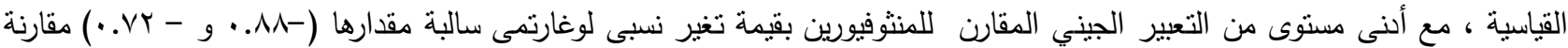

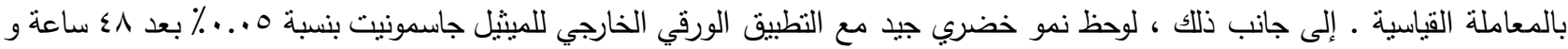

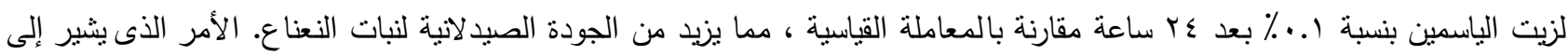

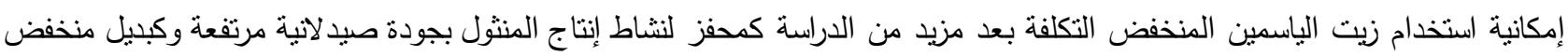
التكلفة للنطبيق الورقي الخارجي للميثيل جاسمونيت. 